\title{
La actualidad de la Lepra en la Republica del Paraguay y su Problema
}

\author{
SEIJI INNAMI \\ (Leprosario Sapucay, Paraguay) \\ ARNAIDO E. ALVARENGA \\ (Director del Departmento de Lepra Ministerio de Salúd Pública y \\ Bienestar Social-Paraguay)
}

La Lepra ocupa un lugar importante entre las enfermedades endemicas como la Leishmaniosis, Chaga y Malaria en el Paraguay. El registro de enfermos de Lepra en el Paraguay ha sido iniciada desde el mes de febrero de 1948 en forma normal, prosiguiendo asi hasta el presente.

El registro de leprosos en los primeros meses de 1948, desde febrero hasta diciembre, se encontraron 399 enfermos entre los 1.355 .000 habitantes en total de la Reública, desde entonces se han descubierto anualmente más de 200 cases nuevos, y a fines del año 1969 habia alcanzado a 6.130 personas.

Mientras tanto, de 1956 al 1968 fue realizada la investiganción de la Lepra por el Ministerio de Salúd Pública y Bienestar Social en forma simultanea y han sido descubiertos 1.794 casos nuevos durante el periodo de tres años, esto indica la alta proporcion en un promedio de $36,4 \%$ por cada CIEN ML habitantes.

El Leprosario de Santa Isabel es una dependencia del Ministerio de Salúd Pública y Bienestar Social y fue fundado en el año 1932, distante alrededor de 100 Kilometros de Asunción, Capital de la República. Los edificios principales fueron construidos en 1946 en colaboracion con el Servicio Cooperativo Interamericano de Salúd Pública. Viven actualmente en el Leprosario 300 enferoms leprosos, en donde se prestan atenciones medicas a los leprosos internados y a los que reciden el la población vecina.

En 1969 Deutsches Aussätzigen Hilfswerk de Würzburg, Alemania, financió la construccion y equipo de un Servicio de Cirugia.

El aumento anual de enfermos, con limitados presupuestos, escasos leprólogos y enfermeros auxiliares, enfrentará con muchas dificultades en el proyecto de control de Lepra en el futuro, sin embargo con el auspicio del Departamento de Lepra del Ministerio de Salúd Pública y Bienestar Social con la colaboración de Deutsches Aussätzigen Hilfswerk y del Japón, les idstrucciones, tratamientos, rehabilitación y prevenciónt etc. de la afección contra la Lepra se encuentra adelantando eficazmente. 


\title{
パラグアイ共和国における瀬の現状と問題点
}

\author{
印南成司 \\ (パラグアイ国サプカイ㿎療盖所) \\ ARNALDO E. ALVARENGA \\ (Director del Departamento de Lepra Ministerio de Salúd \\ Pública y Binestar Social Asunción-Paraguay)
}

（受付1971年 4 月27日）

\section{パラグアイ共和国の概要}

パラグアイ共和国は南米のほぼ中央に位置しており， アルゼンチン，ブラジル㧍よびボリビアの三カ国に围ま れた内陸国で面積は 406,754km²(日本の約1.1倍)で地勢 は一般に平原であり国内の海抜最高は645mにすぎない。

気候は 9 月 4 月が夏型， 5 月〜 8 月が冬型で夏期仙 38度以上の猛暑で，日によっては日中気温40度に達する こともある。冬型は一日の内に夏と冬が来ると称される くらいに変化の激しい不順な気温となる。一日に20度近 い気温の格差を示すことは度々である。雨量は年平均 1,225 ミリ程であるが，その降雨状況は大方は集中豪雨 的である。

パラクアイ国は16世紀のポルトガル，スペインの南ア メリカ探検により1537年に発見され，征服，開発とゅう 形で世界史の中に登場してきた。そして1811年スペイン 植民地領より独立するにいたった。したがって住民の 95 \%まではガラニー族とスペイン人の混血であり，言語， 宗教，文化㧍よび建築なども多くその影響を残してい る。パラグアイ国の人口は1962年の国勢調查（10年每 の実施）に上れば1,819,103人となっているが現在は $2,300,000$ 人と推定されている。

\section{パラグアイ共和国における痺病対策の概略}

パラグアイ国に掠いてはレイシマニア，シヤガ，マラ リヤのよらな地方病のらちでも㿎病はきわ好て重要な地 位を占めている。したがってパラグアイ国に打ける癩 病対策は厚生省に上り1948年 2 月より本格的に始められ 現在にいたっている。鼠病患者の登録も初年度の1948年 には全人口 $1,355,000$ 人の中から399名が登録された。以
来毎年 200 名以上の新患者が発見され，1969 年末には 6,130名にも達している。その間1956年から1958年にか けて，厚生者による䫅の一斎調查が行なわれ。3 年間に 1794名の患者が発見された（人口10万につき平均 $36.4 の$ 高以発生率)。

国立㜚療甆所は1932年に共和国の首都アスンシオンよ り約 $100 \mathrm{Km}$ 離れた地点に厚生省の管轄下に設定され， 主たる建物汒1946年に公衆衛生沉米協力会の協力で建て られた。1969年にはドイツ救麻協会の経済援助により， 手術室および手術用機材一式が整い内容の充実がはから れている。

療養所には約 300 人の患者が生活しており，厚生省 注入院患者および近辺に住む患者に治療と生活援助を提 供している。

現在は厭生省㿎部門が中心となり，ドイッ救癩協会と 日本国政府の協力のもとに，啓蒙，治療，リハビリテー ション，予防等に頻病対策事業が積極的に押し進められ つつある。

\section{新患者発生率}

1948年 2 月より 1969年12月迄の 22 年間に新患者として 厚生省瀨部門に登録された患者の推移は第 1 表に示す如 く，1956年～1958年の 3 年間の一斎調查を除くと平均発 生率怯, 人口 100,000 に対して $11 \sim 13$ 人である。一斎調 查期間は約 3 倍の高以発生率を示す。患者総数注 6130 名 に達している。

\section{患者の病型}

第 2 表は1948年 2 月 1969年12月までに厚生省癩部門 に登録された総患者数6130名の病型別で，第 3 表は1969 
Cuadro No-1

Tasa de Incidencia de Lepra por Año Paraguay-Año 1969

\begin{tabular}{l|l|c|c}
\hline Años & Población $\left.{ }^{\times \times}\right)$ & $\begin{array}{c}\text { Casos } \\
\text { nuevos }\end{array}$ & $\begin{array}{c}\text { Incidencia } \\
\text { 100, 000 Hab. }\end{array}$ \\
\hline 1948 & 1355000 & 399 & 29.8 \\
1949 & 1366000 & 210 & 15.3 \\
1950 & $1397000\left(^{\times \times \times}\right)$ & 147 & 10.5 \\
1951 & 1429000 & 154 & 10.7 \\
1952 & 1462000 & 169 & 10.2 \\
1953 & 1496000 & 150 & 10.6 \\
1954 & 1530000 & 121 & 7.9 \\
1955 & 1565000 & 132 & 8.4 \\
$1956\left(^{\times}\right)$ & 1601000 & 452 & 28.2 \\
$1957\left(^{\times}\right)$ & 1638000 & 855 & 52.1 \\
$1958\left(^{\times}\right)$ & 1687000 & 487 & 28.8 \\
1959 & 1728000 & 218 & 12.6 \\
1960 & 1770000 & 229 & 12.9 \\
1961 & 1803000 & 273 & 15.1 \\
1962 & $1816890\left(^{\times \times \times}\right)$ & 381 & 20.9 \\
1963 & 1892000 & 350 & 18.0 \\
1964 & 1935500 & 236 & 12.2 \\
1965 & 1981000 & 223 & 11.3 \\
1966 & 2017000 & 229 & 11.3 \\
1967 & 2070700 & 298 & 14.3 \\
1968 & 2125500 & 231 & 11.0 \\
1969 & 2181900 & 199 & 9.1 \\
& & &
\end{tabular}

(x) Año del Censo de Lepra

$(x x)$ Poblacián Estimada

$(x \times x)$ Población censal

年12月現在の登録患者4612名の病型別省示している。第 2 表，第 3 表によると麻腫型が約 $50 \%$ と多数を占めてお り，次に類結核型が $28 \sim 30 \%$ ，未分化群が $19 \%$ 。ボーダ 一ライン群が約 $2 \%$ を占めている。

\section{患者の変動}

過去 22 年間に登録された患者総数 6130 名のうち死亡 者540名 (L：385, T: 105, I : 48, B：2), 治癒者765 名 (L：82, T: 457, I：226, B：0), 転居者213名 (L: 91，T: 53，I：67，B:2) で1518名が登録より除 かれた。したがって推定人口 $2,182,000$ (1969年) で registered rate は人口 1,000 人に対して 2.1 を示す。

\section{患者の分布}

パラグアイ国は医療行政上第 I 地区から第V地区に区 画されている（1970 年度よりV区画に分画された）。第
Cuadro $\mathrm{No}^{-2}$

Distribucion Porcentual de Casos de Lepra Fichados hasta el 31-XII-1969

\begin{tabular}{l|r|r}
\hline Formas Clinicos & Casos & $\%$ \\
\hline Lepromatoso & 2900 & 47.4 \\
Tuberculoide & 1893 & 30.8 \\
Indeterminado & 1222 & 19.9 \\
Bordeline & 115 & 1.9 \\
\hline \multicolumn{1}{c}{ Total } & 6130 & 100.0 \\
\hline
\end{tabular}

Cuadro No-3

Distribucion Porcentual de Casos de Lepra ol 31 de Diciembre de 1969

\begin{tabular}{l|r|r}
\hline \hline Formas Clinicas & Casos & $\%$ \\
\hline Lepromatoso & 2312 & 50.3 \\
Tuberculoide & 1278 & 28.0 \\
Indeterminado & 881 & 19.3 \\
Bordeline & 116 & 2.4 \\
\hline \multicolumn{1}{c|}{ Total } & 4612 & 100.0 \\
\hline
\end{tabular}

V地区は首都アスンシオン地带，第 I 地区注首都近県地 帯で，この地区に国立癩療養所がある。第IV地区は西北 部のチャコ地方と称される。塩分の多い大荒野地带であ る。

患者の分布密度 (1968年)は $100 \mathrm{Km}^{2}$ あたり第 V地区の 首都アスンシオン地带が 805,50 と一番高く，最低は第 $\mathrm{IV}$ 地区のチャコ地方で 0.12 , 平均は 0.82 である。パラグ アイ国人口の約 $1 / 2$ は首都アスンシオン市を中心とする $200 \mathrm{Km}$ 圈内に生活している。この圈内はほぼ第 I 地区 と第V地区であり患者総数の約 $2 / 3$ が集約している。

\section{患者の治療状況}

第 4 表の如く厚生省の治療管理下にある患者は $53.6 \%$ で,その他約 $50 \%$ は放置状態にある。患者入院施設は国立 サプカイ療養所に䄪 300 名と，宗教団体(メノニタ教)で 運営しているメノ二タ病院約 30 名の 2 力所にすぎない。

Cuadro $\mathrm{No}^{-4}$

Porcentaje de Casos Bajo Control-1969

\begin{tabular}{c|c|c}
\hline Numero & Controlados & $\%$ \\
\hline 4612 & 2483 & 53.6 \\
\hline
\end{tabular}




\section{問題点および考察}

\section{1）国家予算の問題}

年々 200 名以上の新患者が発見され，患者は蓄積する 一方であり，それに伴なら国家予算の急增は困難であり また不可能でもある。したがって発展途上国パラグアイ においては, Leprosy Control Projects のスピードも 減少して計画通りに進まない。

2) 医師, 補助要員の不足

国立アスンシオン大学医学部は毎年50名の卒業生を社 会に送りだすが，そのらち30\%はアルゼンチン，アメリ カ,ブラジル流出する傾向である。現在約 800 名いる 医師の70\%は首都 Asunción とその周辺に集中して, 僻 地には無医村が多い現状にある。特に Leprosy Control Projectsに関心を抱く医師，補助要員はきわめて少な w。

3) 偏見亡無智

パラグアイ国においては貧富の差が甚だしく，特に農 村において影著である。その上医痖費がきわめて高い ためわずかな皮膚疾患や傷程度で受医する者はまず少な い。療養所に送られてきた患者の多くはすでに初発症状 から10年近い年月を過ごしてきており，四肢に後遺症を 残した者であったり，また農村では素足で歩く所為で， 難治性の足穿孔症を持った者が非常に多い。一般住民の 預困々㿎に対する無智，そして智者や富裕者の癩に対す る強い偏見は癩の早期治療を困難なむのにしている。

4) 社会的疾病としての癩

基本的には筫困と関連してくるが，パラグアイ国にお いては瀬患者が家族に多発にみられる。カトリック教国 なので多産であり（農村では平均 8 人）避娃注されな い。小さな家でひとつのベットに 3 亿人が寝るのは 普通である。生活環境の悪さ，食生活内容の貧しさ等癩 の感染と発病に好条件を備えている状態である。（パラ
グアイ人には南米特有のおおらかさがあり，どんなに䝯 しくても彼等から悲惨さは感じられない)。

医療行政の不備と相まって, 交通事情の悪さ, 特に農 村では想像以上の不便さであり，雨が降れば歩行も困難 となり多くの道路は道路保護の目的で遮断される。した がって患者の規則的な治療も，follow up もおうおうに して困難である。

上述の如く Leprosy Control Projects の前途には色 々な困難が予想されるが，パラグアイ国厚生省癩部門が 中心となり，西ドイッ，日本の協力のもとに，一般大衆 への啓蒙, 補助要員の養成, 外来治療の確立, リハビリ テーションを主体として，入院治療および癩患者多発地 区での15歳以下の学童への BCG 接種等癩病刘策事業が 歩み始めつつある。

㧍わりにパラグアイ国政府の要請により海外技術拹力 事業団 (OTCA) よりパラグアイ国厚生省瀬部門䫏問と して1970年12月に派遗されております。この論文につい ても種々と御援助をいただいた OTCA 医療協力部, 後 藤部長，石塚氏及び関係者の方々に嬮く感謝いたしま 寸。又在バラグアイ国日本大使館より資料その他の御助 カを下さったことに深甚の謝意を表します。

\section{参考文献}

1) Ministerio de Salúd Pública y Binestar Social, Department de Epidemilogia y Zoonosis : Evaluatióndel Programa de Control de Lepra, Parag day, Año 1968.

2) Ministerio de Salúd Pública y Binestar Social; Informe sobre el Programa de Control de la Lepra preparado para la Quinta Reunion Sanitaria de los Paises de la Cuenca del Rio de la Plata. Agost de 1961.

3) INNAMI, S. et al. : Para el mejor Conocimiento de la Lepra. Ministerio Salúd Pública y B. S, Paraguay Año 1971. 